\title{
A Circular Causality Analysis on the Determinants of the Audit Fees within the NYSE-Quoted Companies
}

\author{
Ionela-Corina Chersan, Ioan-Bogdan Robu, Mihai Carp and Marilena Mironiuc
}

"AL. I. CUZA" University of Iaşi, Romania

\begin{abstract}
According to the International Standards on Auditing, audit fees are the amount that remunerates the financial auditor's activity, the certification of financial statements. The Profession Code states that these fees should be calculated in an objective way and the auditor's independence shouldn't be influenced by them. This study aims to identify the determinants of the audit fees, by testing the existence of a circular causality in the connection between audit fees and the financial performance of a NYSE-quoted company. The analysis is based on a sample of the first 100 companies (NYSE quoted) of the Top 500 Fortune, except for the companies in the investment funds and insurances field. In the study there were tested and validated the following working hypothesis: "the level of the audit fees is mainly influenced by the company's capacity to continue its activity", "the prestige of the audited company contributes to the decrease of the audit fees" and "the reduced fees level, paid by the customer audited by one of the Big 4 companies in this exercise, contributes to the future prestige increase". For data analysis there were used linear regression analysis (simple and multiple) and the variance analysis (ANOVA). Research results indicate the existence of a circular causality, bidirectional, on the level of the relationship between audit fees and financial performance. For data processing, in the study there were used statistical software SPSS 19.0 and AMOS 16.0
\end{abstract}

Keywords: audit fees, financial performance, influence factors, circular causalities, linear regression analysis, ANOVA.

\section{Introduction}

Studies regarding the audit market and its actors (auditors and auditees) have been performed for more than 30 years. Many of them point the audit fees and their determinants. Consequently, more and more determinants of audit fees have been identified during this time, and it has been settled that the impact of these factors on the fees level is mostly contradictory (Cobbin, 2002). Among the determinants of the audit fees Hayes et al. (2005) mentions the following: the auditee's size and the geographical dispersion, the size of the audit company, the level of consulting services, the quality of the auditee's internal control system, the type of contract regarding fees (fixed fees against variable fees). Moreover, Hayes et al. (2005) remarks at the Big4 companies the existence a fee raise request, called fee premium. Although most of the studies have pointed out an unidirectional connection between determinants and audit fees, there are studies (Bigus and Zimmermann, 2008 and Danielsen et al., 2009) which prove the existence of a circular causality, meaning that, although they are influenced by some determinants, the audit fees are determinants in their turn for different elements characterizing the auditees and the auditors (for example, the stakeholders' perception of the

Copyright (C) 2012 Ionela-Corina Chersan, Ioan-Bogdan Robu, Mihai Carp and Marilena Mironiuc. This is an open access article distributed under the Creative Commons Attribution License unported 3.0, which permits unrestricted use, distribution, and reproduction in any medium, provided that original work is properly cited. Contact author: Ionela-Corina Chersan E-mail: macov@uaic.ro 
transparency of the audited companies and their performances, as well as the hierarchy of the audit companies).

As far as we are concerned, we aim to check the existence of a circular causality in terms of connection between the audit fees and the financial performance of the companies. Thus, first we will analyze the audit fees and their determinants, and, secondly we will test for validation the proposed work hypotheses in order to point out the existence of a circular causality at the level of the relation between the audit fees and the performance registered by a NYSE-quoted company. Applied to this sample made of the first 100 companies in Top 500 Fortune quoted at NYSE, the study uses the linear regression analysis (simple and multiple) and the variance analysis (ANOVA) in order to validate the work hypotheses and obtain the research results. The results of this study can be useful to both the companies audited by Big 4 companies and the members of Big4 during the fees negotiations, because it proves the circular causality between the fees level and the performance of the audited company.

\section{Audit Fees - General Framework}

Although not clearly defined by the International Standards on Auditing (ISA) or the Statements on Auditing Standards (SAS), in Code of Ethics for Professional Accountants (IFAC, 2010) and in Code of Professional Conduct (AICPA, 2009) the aspects regarding audit fees are extensively analyzed from point of view of the effects the different fees levels may have on the auditor's independence. The audit fees can thus be simply defined as sums payable/paid to the auditor, for the audit services offered to the auditee. In this respect, Code of Ethics for Professional Accountants (IFAC, 2010) establishes that "when entering into negotiations regarding professional services, a professional accountant in public practice may quote whatever fee is deemed appropriate" (Section 240). However, both codes of ethics mention that there may be threats in terms of compliance with the fundamental ethical principles (independence, objectivity, professionalism), when different fees levels are charged. It must be underlined that if an auditor charges a lower fee than another auditor, this is not unethical, if the audit is carried out at a corresponding quality level. An audit mission is considered to be qualitative if it is accomplished according to the applicable technical and professional techniques by a competent audit team. The main criterion of competence assessment is represented in any field by the compliance with some rules for accomplishing each activity. Therefore, we can simply say that an auditor is competent if he is trained according to the customers' needs and if he acts according to the applicable technical and professional standards. At the same time, while to most of the activity types efficiency is a criterion of competence assessment, this criterion is not used in assessing the audit competence, because the audit is not a result obligation, but a means obligation. The noticeable result of an audit mission is the reported opinion, but its pertinence is difficult to evaluate. So not efficiency prevails in the audit field, but competence, which makes the auditor to accomplish all tests and apply all procedures, so that the reported opinion, favourable or not, offers a high degree of assurance with regard to the quality and veracity of the financial information.

In the last years, the big financial scandals generated by the auditors' and their customers' lack of integrity led to the decrease of trust in the capital market and the involved ones (companies, auditors and even surveillance bodies). For this reason, the regulators are getting more and more preoccupied with the way auditors observe the ethical requirements. Both International Federation of Accountants (IFAC, 2010), and the Securities and Exchange Commission (SEC, 2001) insist on the need that auditors are independent in fact and in appearance. Starting from this request, studies (Higgs and Skantz, 2006; Krishnan et al., 2005; Francis and Ke, 2006) have been accomplished proving the extent to which fees for audit and nonaudit services influence independence. Other authors (DeAngelo, 1981; Ashbaugh et al., 2003; Chung and Kallapur, 2003) 
instead, having as starting point the economic theory in audit, suggest that the auditors' temptation to compromise their independence depends on the client's importance, and not on the fees level for non-audit services.

As the audit mission means going over all levels established by standards or professional guides, as it is, according to the literature, a means obligation and not a result one (une obligation de moyen et non de resultats), one can assume that the fee level for the audit missions is generally established according to the work volume of the audit team. However, we can say this is not the main criterion. There are many other factors which determine a higher or a lower level of the fees charged by the auditor from his clients. The literature about the factors that influence the audit fees is voluminous (Simunic, 1980, 0'Keefe et al., 1994; Ezzamel et al., 1996; Moizer, 1997, Craswell and Francis, 1999, McMeeking, 2000, Niemi, L., 2002, Cobbin, Ph. E., 2002, Nikkinen, J, Sahlström, P., 2004, Carson, E., Fargher, N., 2007, Boo, E., Sharma, D., 2008, Hay, D., Knechel, W.R., Ling, H., 2008, Zaman, M., Hudaib, M., Haniffa, R., 2011, Fukukava, H., 2011, etc.). Most of the studies have led to the conclusion that the big audit companies will get higher fees due to their reputation, but there are also differences within this group. The uninterrupted dominance of the accounting and audit companies (in Big 8; Big 6, Big 5, Big 4 format and any other format) on the market of accounting and audit services confirms hypotheses such as: clients prefer to be audited by companies with good reputation, because this can bring advantages to them. High audit fees are usually charged by audit companies which offer high quality services, the companies requesting the services of the top audit companies are usually stock exchange-listed or intend to be.

\section{Influence Factors of the Audit Fees}

One of the first theories regarding the determinants of the audit fees was developed by Simunic (1980). He thinks and proves that the level of the audit fees depends first on the auditor's effort. The connection between the "price" of the audit and the effort for its accomplishing is a natural one, because any audit mission is carried out according to some compulsory standards and rules established by professional auditing organizations. Simunic (1980) also proved the direct connection between the level of the audit fees and the subsequent litigation risk. Referring to this statement, Pratt and Stice (1994) underline that the auditor's evaluation in terms of possible losses in future litigations may result in an increase of the audit effort in order to reduce this litigation risk, and, consequently, to a raise of the audit fees.

In the last years the studies regarding the determinants of the audit fees have also focused to newer directions, such as: the connection between the non-audit services a client benefits from and the level of the audit fees, the connection between the quality of the corporate governance and the audit fees, the influence of the auditor's specialization on the level of the charged fees, the impact of the internal control on the audit fees, the theory of the audit agency and fees. Ezzamel et al. (1996, 2002) proved that there is a direct connection between the non-audit services a client benefits from and the level of the audit fees, and they vary in terms of nonaudit services categories. Ezzamel et al.say there is a positive association between the fees paid for the non-audit services and the audit fees and this connection rather depends on the features of the customer company (the company complexity, events which required more audit and non-audit services) than on the actual costs of the audit and non-audit services. Furthermore, these authors say that the existence of an audit company offering consulting may exercise competitive pressure on the fee of the external auditor. We can suppose that the companies requesting non-audit services are big and have a complex activity, which is why the risk the auditor will associate to that client will be high.

The auditor's perception with regard to the risk associated to the client has traditionally played an important role in fees negotiations, many studies indicating 
that a high risk level associated to the client also generated a high level of the fees charged by auditors from those clients (Cobbin, 2002; Hay, Knechel, \& Wong, 2006). Although most of the studies identify a fees raise in case of the "risky" clients, it is still unclear if this raise is due to the auditor's work volume increase or it can be considered a premium due to higher probability of subsequent litigations, generating additional costs for the auditor (Bell, Landsman, \& Shackelford, 2001; Lyon \& Maher, 2005; Niemi, 2002).

Some studies (Carcello, Hermanson, Neal, Riley, 2002; O’Sullivan, 2000), starting from Simunic's (1980) theory, underline the association between the existence of a managing committee made of nonexecutive directors and the high level of audit fees due to the transfer of a part of the non-executive directors' monitoring activity to the external auditor. A more recent study of O'Sullivan, N. (2009) examines the impact of an insurance conclusion by the directors and officers of the company on the audit fees. The existence impact of this insurance on the audit fees is marked by a duality. On one hand, it can be considered that the existence of additional funds for satisfying the stakeholders' claims in case of bankruptcy of the audited company will result in lower audit fees, because the auditors will no longer be the favorite target in case of litigations, under the pretext that they are the only to be solvable. On the other hand, it was noticed there is a positive connection between the conclusion of this insurance and a number of characteristics traditionally associated to the expensive audit missions (the size and the complexity of the company, a high level of audit risk).

Fukukava (2011) proposed to investigate whether and to what extent the audit determinants examined in the researches so far influence the audit fees on the Japanese market and examine whether the fees charged by the Japanese audit companies and their cost strategies are significantly different. The study revealed that some determinants, such as: the client's size and complexity, the audit risk, the stock market quotation of the company, the market share of the audit company in that field, and the client's power to negotiate, influence the cost of the audit. Other variables, such as the client's location, the closing date of the financial year and the features of the audit company, influence either only the audit fees, or only the audit cost, or both, but in opposite directions. The author remarks that most of the studies focused on the audit fees, while very little pointed the audit costs from the auditor's perspective.

A very interesting study is the one realized by Niemi (2005). His starting point is an observation: the studies of the audit fees were mainly performed outside continental Europe and never took into consideration the influence of the property structure in the customer-company on the effort and audit fees. The observations of the study were the following: the effort and the audit fees are lower in the case of the companies mainly owned by managers and higher in the case of the branches of foreign companies; no differences have been noticed as far as the effort and the audit fees between the companies owned by the state or municipalities and the companies with a more diverse shareholder structure are concerned.

As supposed, the reference to the agency theory could not miss from the analysis of the audit fees determinants. Nikkinen, J and Sahlström, P. (2004) thus tried to answer the question if the agency theory provides a general framework for establishing the audit fees. According to Jensen \& Meckling (1976), a component of the agency costs is represented by the monitoring costs supported by shareholders for the monitoring of the managers actions. The audit fees are an important component of these costs, as long as auditors have to make sure that managers act according to the shareholders' interests, while also auditors have the required task to inspect the accounts of the company. It may hence be supposed that auditors will spend more time inspecting the managers' activity if the agency problems are big. Consequently, Jensen (1986) suggests that, in the case of the companies whose capital is mainly 
owned by managers, the agency costs are low, because it is more probable that the managers' interests coincide with the shareholders', when managers are also majority shareholders. Therefore, the monitoring costs, including the audit fees, will be higher in the case of the companies whose managers own an insignificant part of the capital (Agrawal \& Jayaraman, 1994, Gul \&Tsui, 2001). The study of Nikkinen, J și Sahlström, P. (2004) confirms that there is a negative relation between the audit fees and the managers' owning the majority of the company capital, while between the audit fees and the free cash flow there is a positive one.

\section{Audit Fees and Financial Performance - A Circular Causality}

In order to prove the existence of this circular causality, the connection among a few key-elements must be observed: the fees level, the audit quality, the financial communication, the affiliation to a certain auditor, the performance of the audited company and the hierarchy of the audit companies.

Starting from the observation that big audit companies charge higher fees than the ones charged by small audit companies, Palmrose (1986) noticed that the services offered by the big companies are high quality. Also Danielsen et al. (2009) consider that an auditor's intervention increases the quality of financial communication (transparency). Consequently, it may be supposed that the intervention of a high reputation auditor (for example member of Big 4) means an important expenditure to the customer company, but will lead to the transparency improvement. The answer to the question: who benefits from this improvement and who will pay such audit fees? was also given by Danielsen et al. - the companies frequently intervening on the capital market. This assertion is sustained by the migration in the nineties of such companies to the big audit companies (at that time Big5). In spite of spending important sums of money on the audit fees, it is considered that the companies that benefit from quality audit services increase their liquidities and decrease the cost of equity capital. Therefore, we can consider that there is a direct connection between the audit fees level and the liquidities of the company. Furthermore, it is supposed that a significant raise of the fees for the nonaudit services results in the liquidity diminishing and, moreover, can compromise the auditor's independence.

Walker, P. L. și Casterella, J. R. (2000) prove that, although in the ' $90 \mathrm{~s}$ there were changes in comparison to the '80s in the auditors' business practices in terms of avoiding risky clients and charging of higher fees from new clients and who feature a higher risk, the practice of granting discounts was maintained in the case of new commitments. Still, while in the ' 80 s these discounts depended on the new client's profitability, in the '90s the auditors were no longer willing to grant discounts if in the year previous to the audit contracting the client had registered losses. Moreover, the authors noticed that these observations are especially valid in the case of companies which want to switch from a non-Big 6 (at that moment) auditor to a Big6 one and to a lower extent in the case of switching wish from a Big6 auditor to another one from the same category (intra Big-6 switches). The result of the research points out that auditors manage the exposing to audit risk by decreasing the audit fees.

Trying to understand the factors underlying the auditor's decision to accept a client, Gendron, Y (2001) also analyses the possible effect of the future client's financial standing on the acceptance decision. The result of his study indicates that a client's acceptance decision is more likely to depend on the auditor's professional competence and independence rather than the potential client's economic situation.

Taking into account these observations, we can assert that a company which pays high audit fees to an audit company with an important reputational capital wants to transmit to stakeholders a positive message regarding its financial standing. Furthermore, beyond the fact that a 
company must already have these sums available in order to pay such fees, the intervention itself of an important auditor will result in the liquidity increase. It must not be ignored that the audit companies, especially the important ones (Big4) usually avoid the association with risky clients or request very high fees if they accept the mission. Consequently, once an important auditor accepts a mission, it is supposed that there will be an improvement of financial communication, and an increase of the stakeholders' trust in the accuracy of the financial standings and audit reporting, respectively. Most of the times, the association between the client's name and a very well reputed auditor leads to the improvement of the way the company is regarded by stakeholders or, in other words, leads to the improvement of the company image.

\section{Research Methodology}

In this research we intend first to accomplish an analysis of the financial and non-financial determinants, the level of the audit fees within the NYSE-quoted companies. Secondly, we will try to point out a circular causality in the connection between the audit fees and the performance of a NYSE-quoted company. From methodological point of view, the study is oriented to a positivistic logical approach, the empirical evidence assuring the validation of the work hypotheses to be tested.

According to Smith (2003), reaching the research objectives means the use of deductive-inductive reasoning, assured by a logical formulation of the hypotheses, but also by objectively capturing the studied reality. Starting thus from the current knowledge level, presented in the literature, a set of work hypotheses will be formulated, validated by means of the empirical results obtained from the preponderantly quantitative analyses.

\section{Work Hypotheses Formulation}

In the specific literature the studies concerning the audit fees pay special attention to determinants. Redmayne et al.
(2011) thus say in their study that the level of the audit fees is diminished by the existence of the audit committees, but also by their efficiency within the audited companies. However, at the level of big corporations, Zaman et al. (2011) say that the functioning of the audit committees based on corporate governance led to the replacement of audit fees with the ones related to consulting services. Cobbin (2002) revises the literature regarding fees, by analyzing their historical, cultural, institutional and insurance market-related extents. Last but not least, Basioudis et al. (2008) consider that the relationship between the audit fees and the ones related to other consulting services have a significant impact on the auditor's independence. Based on this study, the empirical evidence proves that the audit fees influence the auditor's opinion regarding the testing of the going-concern assumption. Moreover, Niemi (2002) considers that fees pay the auditor for the effort at emitting the audit opinion, and the amount of fees contains in this case a risk premium directly proportional to the audit and market risk of the client.

From the perspective of the affiliation to a certain auditor, Basioudis (2007) proves the influence of the former employees of the audit companies and co-opted in the audit or management committees of the clients on the audit fees decrease. Carson and Fargher (2007) notice from the perspective of the determining factors the existence of big differences between the practised audit fees, in terms of the client size, but also the company's activity field. Based on this study, it is proved that big companies from very specialized fields tend to pay higher audit fees than the rest of the audited companies. As far as the correlation between the results of the customer-company and the fees level, Griffin et al. (2010) say that companies with high free cash-flow levels and development perspectives pay additional audit fees in order to compensate the auditor's effort during the mission.

Only the unidirectional relation can be pointed out so far: the influence of some factors (activity field, performance, 
affiliation to an auditor) on the audit fees. But a set of studies, among which the one of Danielsen et al. (2009), lead to the presence of a circular causality in terms of the influence of the fees level (in their turn influenced by the affiliation to a certain auditor) on the stakeholders' perception regarding the transparency of the audited company and thus on performance. Starting from the audit fees, Bigus and Zimmermann (2008) say that their level also determines the hierarchy of the audit companies, the Big4 supremacy being underlined in this respect.

Based on the above-mentioned, we aim in this study to test and validate the following expressed work hypotheses:

$\mathbf{H}_{1}$ : The level of the audit fees is significantly influenced by the capacity of the company to continue its activity. In this respect, we aim to estimate the influence of the financial leverage and the net margin from the previous exercise on the fees practiced by the Big4 companies, in the next exercise.

$\mathbf{H}_{2}$ : The prestige of the audited company contributes to the audit fees decrease. Therefore, we aim to estimate the influence of the position in top 500 Fortune 2010 (obtained due to the results reported in 2009) on the fees practiced by the Big4 companies in 2010. At the same time, we intend to test whether there are significant differences between the fees paid by the audited companies from different value echelons.

$\mathbf{H}_{3}$ : A low fee level paid by the auditee to one of the Big4 companies in the current exercise contributes to the increase of future prestige (explained by the financial performance of the company).

\section{Data Analysis Methods}

The methods of data analysis used in this research for testing and validating the hypotheses are the linear regression analysis (simple and multiple) and the analysis of variance (ANOVA).
The linear regression analysis is an analysis method which permits the value estimation of a result-type variable, considering the values of other variables as factor-type. Jaba (2002) asserts that the linear regression analysis is also used to evaluate the extent to which the dependent (resultative) variable can be explained by means of the independent (factors) variables. Generally speaking, the regression model is: $Y=\beta_{0}+\beta_{1} X_{1}+\ldots+\beta_{i} X_{i}+$ $\ldots+\beta_{2} X_{2}+\varepsilon_{i}$, with $i=1 \ldots n$, where $Y$ represents the dependent variable, $X_{i}$ the independent variables of the model, $\beta_{i}$ are the model coefficients, and $\varepsilon_{i}$ is the random value summing up the variables not included in the model (Gujarati, 2004). The $\beta_{i}$ coefficients are estimated by means of the least squares method. Values of the coefficients $>0$ indicate the existence of a direct connection between the independent variables and the dependent one, values = 0 indicate the absence of any connection, and values $<0$ signal a reverse connection between the factors variables and the resultative one.

Based on the expressed work hypotheses, we suggest the following three linear regression models we want to validate:

$$
\begin{aligned}
& \text { 1. Audit fees } 2010=f(\text { Financial } \\
& \text { leverage } \left.\text { }_{2009} ; \text { Nnet Margin } 2009\right)+\varepsilon_{i} \\
& \text { 2. Audit fees } 2010=f(\text { Position in top } 500 \\
& \text { Fortune } 2010)+\varepsilon_{i}
\end{aligned}
$$

3. Performance of the audited company ${ }_{2010}=$ $f($ Audit fees 2010$)+\varepsilon_{i}$, or analytical:

- Position in top 500 Fortune $_{2011}=f($ Audit fees 2010$)+\varepsilon_{i}$

- Return on Assets $2010=f($ Audit fees 2010$)+\varepsilon_{i}$

- Net Margin $_{2010}=f($ Audit fees 2010$)+\varepsilon_{i}$

ANOVA Between-Subjects will be applied in order to test the existence of significant differences of the fees paid by companies from different echelons. In this case, each audited company belongs to a value echelon, according to the position in Top 
500 Fortune 2010: the first echelon, the second echelon and the third echelon. The unifactorial ANOVA is a method of variance analysis based only on one grouping factor (the independent variable will be in this case the affiliation to a certain value echelon). This method permits the comparison of the average values of the three considered echelons, in order to determine whether there are significant differences between them (Jaba, 2002). When the intragroup variance is weak and the intergroup variance is strong, the result is that the averages of the population groups are different among them (Field, 2005). On the contrary, when the intragroup variance is strong and the intergroup variance is weak, one can speak of group homogeneity (Field, 2005). In order to test the averages variability from one group to another in terms of grouping factor, the ratio of the extent of average dispersion and the dispersion within the groups will be carried out, based on the ANOVA method.

In the case of ANOVA models, the main statistical hypotheses will be taken into account: the independence hypothesis, the normality hypothesis of the dependent variable (audit fees) at groups level, and the independent variable homoscedasticity hypothesis (constant variance). The differences among averages are analyzed by means of the exploratory analytical comparisons, post-hoc tests, and out of these we will use the Bonferroni test.

\section{Variables Analyzed in the Research}

The following variables, synthesized in Table no. 1, have been considered for testing the work hypotheses:

Table no. 1 Variables Used in the Research

\begin{tabular}{|c|l|l|}
\hline Variable & \multicolumn{1}{|c|}{ Significance } & \multicolumn{1}{c|}{ Method of calculation } \\
\hline$F L$ & Financial leverage & Total Liabilities / Equity \\
\hline$N M$ & Net margin & Net Profit / Turnover \\
\hline$R O A$ & Return on assets & Operating Income/ Total Assets \\
\hline Afees $_{2010}$ & Audit fees paid in 2010 & - \\
\hline${\text { Top } 500_{2010}}^{2}$ & Position in Top 500 Fortune 2010 & - \\
\hline Top500 $_{2011}$ & Position in Top 500 Fortune 2011 & - \\
\hline Echelon & $\begin{array}{l}\text { Echelon to which the audited company } \\
\text { belongs }\end{array}$ & $\begin{array}{l}1=1^{\text {st }} \\
=3^{\text {rd }} \text { Echelon, } 2=2^{\text {nd }} \text { Echelon, } 3\end{array}$ \\
\hline
\end{tabular}

(Source: own processing)

\section{Target Population and Sample}

The target population (that we want to know) is represented by the totality of the NYSE-quoted companies, present in Top 500 Fortune. Out of this population, a sample of 100 companies was extracted. The chosen extraction method is the cluster-type, the first 100 companies being selected, except for the companies in the investments funds and insurances field. The dividing of the sample into the three echelons was based on the following reasoning: the first echelon I (contains the first 30 top companies), the second echelon (contains the next 30 companies) and the third echelon (contains the last 40 companies in top 500 Fortune).

According to the activity field, the analyzed sample presents $20 \%$ companies in the commerce field, $37 \%$ companies in the services field, and $43 \%$ companies in the industry field. As far as the affiliation to one of the Big4 companies is concerned, in the analyzed sample were registered $28 \%$ companies audited by Ernst\&Young (E\&Y), 15\% audited by KPMG, 31\% audited by PricewaterhouseCoopers (PwC) and the rest of $26 \%$ by Deloitte. 


\section{Data Collecting and Data Processing Instruments}

The financial $(L F, M N)$ and non-financial (activity field, contracted auditor) data regarding the analyzed companies have been taken over from the situations presented in the EDGAR on-line database (Electronic Data Gathering Analysis and Retrieval), of SEC (U.S. Securities and Exchange Commission).
The data processing has been performed by means of the statistical software, SPSS 19.0 and AMOS 16.0 (for the graphical representation of the regression models).

\section{Research Results and Discussions}

Depending on how the sample is structured, in terms of the activity field of the audited companies or the affiliation to one of the four companies of Big4, a series of descriptive statistics regarding the audit fees level are presented in table no. 2.

Table no. 2. Descriptive Statistics Regarding Audit Fees

\begin{tabular}{|c|r|r|r|r|}
\hline \multirow{2}{*}{ Group } & \multicolumn{4}{|c|}{ Statistics (in millions \$) } \\
\cline { 2 - 5 } & Mean & St. Dev & \multicolumn{1}{c|}{ Min. } & \multicolumn{1}{c|}{ Max. } \\
\hline Industry & 19.81 & 14.93 & 0.53 & 89.80 \\
\hline Commerce & 5.99 & 5.44 & 1.69 & 25.03 \\
\hline Services & 26.01 & 29.36 & 0.96 & 144.50 \\
\hline E\&Y & 12.00 & 7.26 & 0.53 & 30.80 \\
\hline KPMG & 22.66 & 25.88 & 0.96 & 89.80 \\
\hline PwC & 26.36 & 29.51 & 1.23 & 144.50 \\
\hline Deloitte & 16.97 & 15.38 & 2.10 & 61.70 \\
\hline \multicolumn{5}{|c|}{ (Source: own processing in SPSS 19.0) } \\
\hline
\end{tabular}

Based on the information summarized in Table 2 we can appreciate the fact that on average, the highest audit fees were paid by companies from the services field. This is caused by high inherent risk associated to these companies: the difficulty of obtaining accurate records of consumption of raw materials, inability to conduct accurate inventories, propensity to fraud and the complexity of operations. A high level of audit fees for companies from services field can be also explained by the influence of control risk resulting from the operating mode of internal control system. For companies form services field, the implemented control system has to ensure with priority the integrity of the information system. In this situation, in the case of the firms from services field, patrimonial integrity is a secondary objective due to the presence, by excellence, of the intangible assets. Thus, audit fees paid by a company from services field are on average about $\$ 26.01$ million. In contrast, relatively simple and repetitive operations of the firms from commerce field lead to the recording of much lower fees than those that are paid by companies from services field. On average, a commerce firm paid \$ 5.99 million for audit fees.

Regarding the fees charged by audit firms of the Big 4, it can be observed the coverage of the audit services market, the audit fees answering to all requests for audit service and financial certification. Thus, on average the audit fees have a variation from a minimum of $\$ 0.53$ million (charged by E\&Y), up to a maximum of $\$$ 144.50 million (acquired by PWC). However, taking into account the average levels of audit fees of Big 4 firms we can appreciate the existence of polarization at their level. On average, lower rates are charged by E\&Y (\$12.00 million) and Deloitte (\$16.97 million) and higher charges by KPMG ( $\$ 22.66$ million), or even double by PwC (\$26.36 million). This polarization and variety of fees charged determine the maintaining the 
competitiveness of audit firms, with a major impact on audit services quality.

To highlight the influence of the client's financial performance recorded in the previous year on the level of the audit fees paid for subsequent audits, the $H_{1}$ hypothesis proposes studying the relationship between $F L$ and $N M$ as independent variables and audit fees (as the dependent variable). After processing in AMOS 16.0, the following results were summarized in Figure 1.

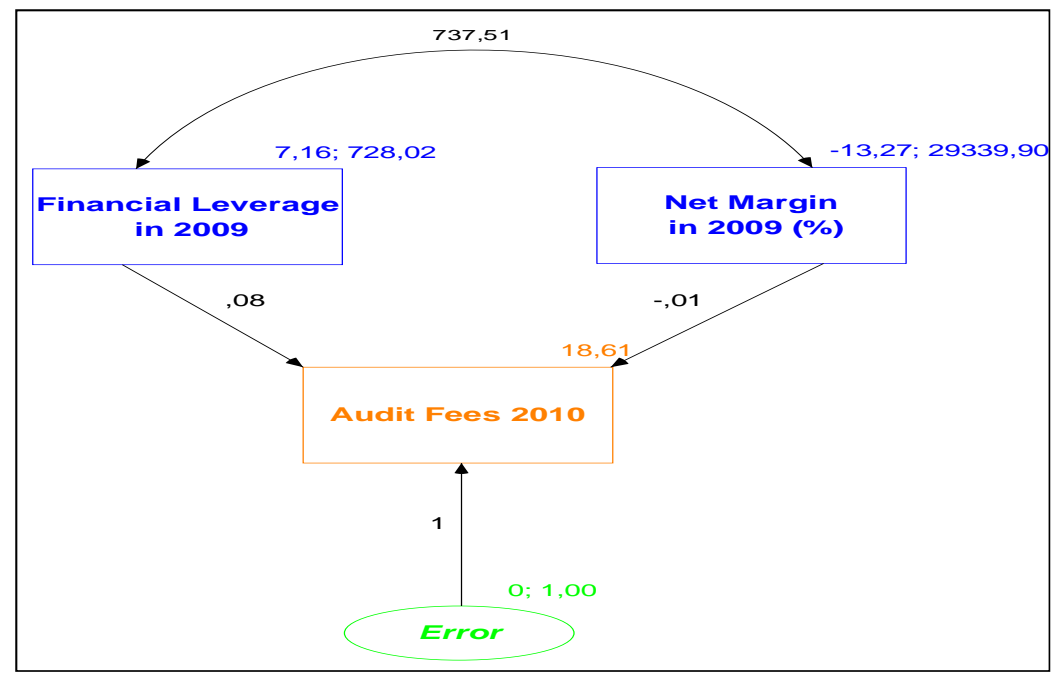

Figure no. 1. The Influence of Performance Indicators on Audit Fees (Source: own processing in AMOS 16.0)

The obtained results show the following regression model which highlights the influence of the $F L$ și $N M$ on the audit fees:

Audit fees $2010 i=18.61+0.08$ Financial
leverage $_{2009 i}-0.01$ Net Margin
$2009 i$
$+\varepsilon_{i}$.

Thus, increased by one degree of financial leverage in the previous financial year would lead to an increase of \$ 0.08 million of the current year audit fees level. Simultaneously, a percentage increase of $N M$ in the previous year audited involves the reduction with $\$ 0.01$ million of the audit fees in the current year. This is explained by additional tests that the audit firm must apply to obtain audit evidence about the client's ability to continue as a going concern. Increasing indebtedness, correlated with a decrease of profitability are financial signs of the inability to continue as a going concern in a predictable timeframe. Testing this hypothesis involves obtaining additional audit evidence that will lead to increase audit fees charged, that would pay the audit risk paid by the auditor.

In the working hypothesis $H_{2}$, to analyze the influence of the audited companies' reputation on the audit fees there were estimated in SPSS 19.0 the regression model parameters. The results are summarized in Table 3.

Table no. 3. The Influence of the Audited Company Prestige on the Audit Fees

\begin{tabular}{|c|r|r|r|c|}
\hline \multirow{2}{*}{ Model } & \multicolumn{3}{|c|}{$\mathrm{R}^{2}=0.072 ;$ F $=7.588 ;$ Sig. $=0.007<0.05$} \\
\cline { 2 - 5 } & Coeficients & Std. Error & \multicolumn{1}{c|}{$\boldsymbol{~}$ Sig. } \\
\hline Place in Top 500 Fortune 2010 & -0.105 & 0.038 & -2.755 & 0.007 \\
\hline Constant & 25.389 & 3.032 & - & 0.000 \\
\hline
\end{tabular}

(Source: own processing in SPSS 19.0) 
Based on the results obtained in SPSS 19.0, the equation model is:

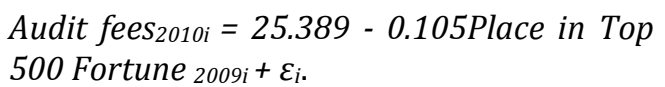

This model indicates that the audit fees variation for the current financial year is explained in a proportion of $7.20 \%$ by the position in Top 500 Fortune 500, obtained in the same year (based on financial performance in the previous year). The remaining variation of the audit fees is logically determined by the complexity of the audit engagement, by the number of hours worked, by the associated audit risk (factors well-known in the literature). Moreover, with a confidence of $95 \%$ (based on a Sig $=0.007$ lower than the materiality level of $0.05 \%$ ) we can say that the climbing with one step in the Top 500 Fortune of a client company involves the decrease of the audit fees with \$ 0.105 million. In conclusion, we consider that the prestige of the audited company (based on Top 500 Fortune) reduces the inherent risk, with a major impact on the audit risk reduction and implicitly on the reduction of the audit fees paid.

Regarding the existence of significant differences between the audit fees on the three levels of performance established, based on analysis of variance (ANOVA) there were obtained in SPSS 19.0 the following results:

Table no. 4. The Estimation of the Differences between Audit Fees Charged, Depending on the Performance Levels of the Audited Companies

\begin{tabular}{|c|c|c|c|c|}
\hline \multicolumn{2}{|r|}{ ANOVA } & \multicolumn{3}{|c|}{$F=6.306 ;$ Sig. $=0.003<0.05$} \\
\hline & $\begin{array}{l}\text { (I) Echelons of Top } \\
500 \text { Fortune } 2010\end{array}$ & $\begin{array}{l}\text { (J) Echelons of Top } \\
500 \text { Fortune } 2010\end{array}$ & $\begin{array}{l}\text { Mean Difference } \\
(I-J) \$ \text { million }\end{array}$ & Sig. \\
\hline \multirow{6}{*}{$\begin{array}{l}\text { Bonferroni } \\
\text { Test }\end{array}$} & \multirow{2}{*}{ 1st Echelon 2010} & 2nd Echelon 2010 & 13.51 & 0.037 \\
\hline & & 3rd Echelon 2010 & 17.12 & 0.002 \\
\hline & \multirow{2}{*}{ 2nd Echelon 2010} & 1st Echelon 2010 & -13.51 & 0.037 \\
\hline & & 3rd Echelon 2010 & 3.61 & 1.000 \\
\hline & \multirow{2}{*}{ 3rd Echelon 2010} & 1st Echelon 2010 & -17.12 & 0.002 \\
\hline & & 2ndEchelon 2010 & -3.61 & 1.000 \\
\hline
\end{tabular}

(Source: own processing in SPSS 19.0)

After applying ANOVA to the analyzed sample, we can appreciate the existence of significant differences (Sig. $=0.003<0.05$ ) in the audit fees paid by companies belonging to the three echelons of performance considered, according to the position occupied in the Top 500 Fortune 2010. With a 95\% confidence we can say that a company form the first echelon pays with \$13.51 million more audit fees than a company from the second echelon, and with \$ 17.12 million more than firms from the third echelon. Although, on the analyzed sample, using the Bonferroni test, are shown a series of differences between the fees paid by companies in the second and third echelons, statistically the differences are insignificant (Sig. = 1> 0.05). Based on these results we can conclude that companies with higher positions in the Top 500 Fortune 2010 (1st Echelon) pays much higher audit fees that the audit companies from the second or third echelons, just to enhance prestige and to reinforce the perception of stakeholders on the accuracy of reported financial statements. A high level of audit fees corresponds to a considerable number of hours worked, with a major impact on the quality of the audit engagement. Thus, the allocation of additional mission hours to obtain sufficient appropriate audit evidence can lead to increased accuracy of the audit opinion expressed.

If the validation of the first two hypotheses ( $H_{1}$ and $H_{2}$ ) has shown that the previously recorded performance of the audited companies has a significant impact on the current audit fees, by the validation of 
working hypothesis $H_{3}$, we want to demonstrate that the level of audit fees for the current audit engagements contributes significantly to the variation of the subsequent companies performance.

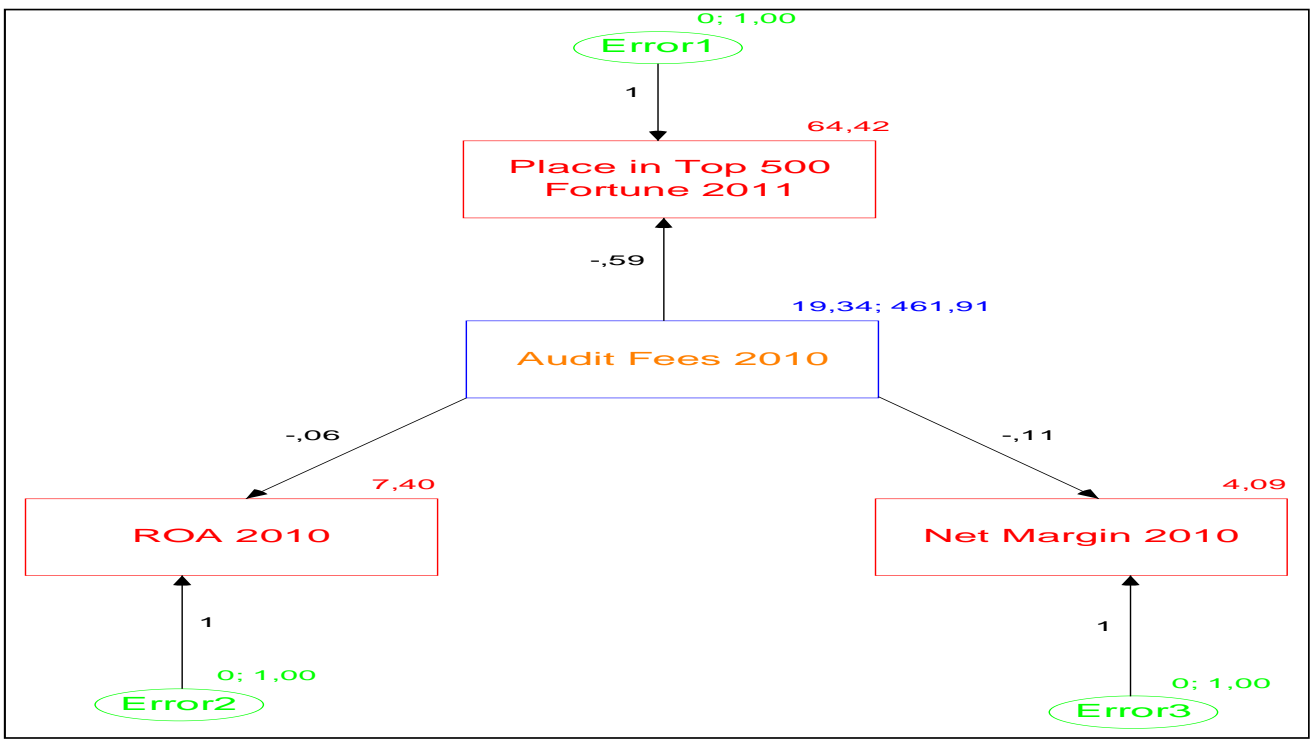

Figure no. 2. The Influence of Audit Fees for Current Missions on Performance Indicators Reported in the Next Financial Year

(Source: own processing in AMOS 16.0)

The results obtained in AMOS 16.0, summarized in Figure 2, shows the influence of the audit fees for the current financial year (2010), to the performance indicators: $R O A_{2010}, N M_{2010}$ and Place in the Top 500 Fortune 2011. Also keep in mind that although audit fees corresponding to the financial year 2010, the tariffs are known since the signing of the audit engagement. Logically and in accordance with ISA and SAS, the calculation of these charges should not take into consideration the future financial results recorded by the audited company.

Based on the results in Figure 2, the influence of audit fees on the audited company performance can be expressed by the following three regression models:

- Pozition in top 500 Fortune $_{2011}=64.42$ 0.59 Audit fees $2010+\varepsilon_{i}$

- Return on Assets $2010=7.40$-0.Audit fees $_{2010}+\varepsilon_{i}$

- Net Margin $_{2010}=4.09-0.11$ Audit fees $2010+$ $\varepsilon_{i}$.
The effect of the other exogenous factors (operational and financial) which affect in a significant proportion the company performance are highlighted in each model by using the error factor (Error 1, Error 2 and Error 3).

Thus, with $95 \%$ confidence we can say that variation of the audit fees in the current year explains, in addition to other operational and financial factors, the variation in the proportion of $16 \%$ of the position in Top 500 Fortune 500 occupied next year, of $5.3 \%$ of the economic profitability (ROA) and only of the $0.3 \%$ of the net margin. Moreover, an increase of $\$$ 2 million of audit fees in the current year determines the decrease with one position $(1 \approx 2 \times 0.59)$ in the Top 500 Fortune, of the audited company in the following year. At the level of financial performance ratios, $\$$ 1 million reduction in audit fees for the year 2010 helps to increase by $6 \%$ to $R O A_{2010}$ and increased by $11 \%$ of $N M_{2010}$.

Although in the literature (Danielsen et al., 2009) there is specified that a high level of audit fees contributes to the quality of 
reporting, in terms of results, the audit fees are cost for the audited company, which reduces the operating result and implicitly $R O A$ and $N M$. The high costs involved in a audit engagement, expressed through fees paid by the client, have behind a volume of working hours and audit evidence obtained to substantiate the auditor's opinion. An increasing number of mission hours can express a deeper part of certification accuracy of financial information reported in certain areas, or a need to obtain additional evidence under the non effectiveness of the internal control system. Finally, a high level of fees can also lead to the impairment of the auditor's independence. Thus, over-evaluation of services rendered by the auditor (in term of fees) can favorably influence the final audit opinion. From this point of view, business relationships with all stakeholders can all suffer, which would bring down the prestige, the creditworthiness and financial performance.

\section{Conclusions}

The study of the audit fees charged by the major audit firms of the Big 4 group, and also of the determinants is a complex process that must be correlated with their impact on the performance of audited companies.

The validation of the three working hypotheses, which were proposed in this study, follows the existence of correlation between audit fees and certain performance indicators. Thus, we have determined and estimated the direct influence of financial leverage and net margin on audit fees. It was noted that an increase in audit fees is when indebtedness of the company is increasing and the net margin is decreasing (signs of business failure). This leads to pay a higher audit risk that is taken by the auditor.

Finally, it notes that the advancement in Top 500 Fortune, in the current year (based on performances from the previous year) leads to lower audit fees. This is explained by the lower inherent risk associated to the audited companies, and increasing of creditworthiness and prestige determine the obtaining of sufficient appropriate audit evidence regarding the accuracy of reporting. Therefore, the audit engagement would have a minimum number (required by the profession) of working hours that will lead to the payment of reduced audit fees.

Also the results obtained demonstrated that the companies from the leading positions in the Top 500 Fortune tend to pay much higher audit fees than the firms from the lower echelons. This may indicate a prestige-building policy and stakeholder perception of the accuracy of reporting.

In terms of influence of the audit fees on the performance of the company, this relationship should be also treated from the perspective of the associated cost to the audit engagement, that cause the decrease of the recorded result (operating or net) and implicitly of the firm performance. Moreover, a high level of audit fees, without a foundation of a real mission hours, may lead to impairment of auditor independence. This may causes the loss of firm's prestige, the deterioration of relations with business partners (customers, suppliers, state) and can lead to lower performance.

Based on the proven, we can say that the relationship performance - audit fees is bijective, identified causality manifests circularly: a company with negative results presents a high inherent risk (based on testing the Going Concern assumption, which would lead to an increasing of audit fees in the following year, to pay the audit risk assumed by the auditor. Further, costs that are associated to the fees reduce the operating results, with a major impact on reducing the rates of return (economic and commercial). In the absence of recovery policies in the companies audited, these results may cause long-term loss of credibility and stakeholder support.

Although the study is limited by the use of a reduced number of indicators that define the company's financial performance and prestige (FL, NM, ROA and Position in Top 500 Fortune) the future research directions 
would follow the introduction in the analysis of other indicators, and the identification of those who explains a significant proportion of variation in audit fees. Moreover, the study identified causality can be analyzed according to the activity field of client companies and according to membership of a particular auditor, member of the Big 4.

From the methodological point of view, the use of statistical methods within the financial audit mission, as well as the interconnection between the results and the financial analysis and accounting may open a new research direction. This new field, aiming to analyze the economic and financial phenomena within the financial audit, based on some indicators of financial analysis by means of advanced statistical and econometrical methods, is hypothetically called auditometrics.

\section{Acknowledgements}

This work was supported by the the European Social Fund in Romania, under the responsibility of the Managing Authority for the Sectoral Operational Programme for Human Resources Development 2007-2013 [grant POSDRU/CPP 107/DMI 1.5/S/78342].

\section{References}

Agrawal, A. \& Jayaraman, N. (1994). "The Dividend Policies of All-Equity Firms: A Direct Test of the Free Cash Flow Theory," Managerial and Decision Economics, 15, Pp. 139-148.

American Institute of Certified Public Accountants (AICPA) (2009). Code of Professional Conduct.

Ashbaugh, H., Lafond, R. \& Mayhew, B. W. (2003). "Do Non-Audit Services Compromise Auditor Independence? Further Evidence," The Accounting Review, 78 (3), Pp. 611-639.

Basioudis, I. G. (2007). “Auditor's Engagement Risk and Audit Fees: The Role of Audit Firm Alumni," Journal of Business
Finance \& Accounting, 34 (9 \& 10), Pp. 1393-1422.

Basioudis, I. G., Papakonstantinou, E. \& Geiger, M. A. (2008). "Audit Fees, NonAudit Fees and Auditor Going-Concern Reporting Decisons in the United Kingdom," ABACUS, 44 (3), Pp. 284-309.

Bell, T. B., Landsman, W. R. \& Shackelford, D. A. (2001). "Auditors' Perceived Business Risk and Audit Fees: Analysis and Evidence," Journal of Accounting Research, 39, Pp. 35-43.

Bigus, J. \& Zimmermann, R.- C. (2008). "Non-Audit Fees, Market Leaders and Concentration in the German Audit Market: A Descriptive Analysis," International Journal of Auditing, 12, Pp. 159-179.

Boo, E. F. \& Sharma, D. (2008). "Effect of Regulatory Oversight on the Association Between Internal Governance Characteristics and Audit Fees," Accounting and Finance, 48, Pp. 51-71.

Bragg, S. M. (2010). Wiley Practitioner's Guide to GAAS 2010: Covering all SASs, SSAEs, SSARSs, and Interpretations, John Wiley \& Sons, New Jersey.

Carcello, J. V., Hermanson, D. R., Neal, T. L. \& Riley, R. A. (2002). "Board Characteristics and Audit Fees," Contemporary Accounting Research, 19, Pp. 365-384.

Carson, E. \& Fargher, N. (2007). "Note on Audit Fee Premiums to Client Size and Industry Specialization," Accounting and Finance, 47, Pp. 423-446.

Chahine, S. \& Filatotchev, I. (2011). "The Effects of Corporate Governance and Audit and Non-Audit Fees on IPO Value," The British Accounting Review, 43, Pp. 155-172.

Chung, H. \& Kallapur, S. (2003). "Client Importance, Non-Audit Services, and Abnormal Accruals," The Accounting Review, 78 (4), Pp. 931-955.

Cobbin, P. E. (2002). "International Dimensions of the Audit Fee Determinants 
Literature," International Journal of Auditing, 6, Pp. 53-77.

Craswell, A. T. \& Francis, J. R. (1999). "Pricing Initial Audit Engagements: A Test of Competing Theories," Accounting Review, 74, Pp. 201-216.

Danielsen, B. R., Harrison, D. M., Van Ness, R. A. \& Warr, R. S. (2009). "REIT Auditor Fees and Financial Market Transparency," Real Estate Economics, 37 (3), Pp. 515-557.

DeAngelo, L. E. (1981). "Auditor Size and Audit Quality," Journal of Accounting and Economics, 3 (3), Pp. 183-199.

Ezzamel, M., Gwilliam, D. R. \& Holland, K. M. (1996). "Some Evidence from Publicly Quoted U.K. Companies on the Relationship between the Pricing of Audit and NonAudit Services," Accounting and Business Research, 27 (1), Pp. 3-16.

Ezzamel, M., Gwilliam, D. R. \& Holland, K. M. (2002). "The Relationship between Categories of Non-Audit Services and Audit Fees: Evidence from UK Companies," International Journal of Auditing, No. 6, Pp. 13-35.

Financial Executive Research Foundation, (FERF) (2009). Audit Fee Survey.

Field, A. (2005). Discovering Statistics Using SPSS, 2nd Ed. (And Sex, Drugs and Rock'n' Roll), Sage Publications, London.

Francis, J. R. \& Ke, B. (2006). "Disclosure of Fees Paid to Auditors and the Market Valuation of Earnings Surprises," Review of Accounting Studies, 11 (4), Pp. 495-523.

Fukukava, H. (2011). "Audit Pricing and Cost Strategies of Japanese Big 3 Firms," International Journal of Auditing, No. 15, Pp. 109-126.

Gendron, Y. "The Difficult ClientAcceptance Decision in Canadian Audit Firms: A Field Investigation," Contemporary Accounting Research; Summer 2001, 18 (2), Pp. 283-310.
Ghosh, Al., Kallapur, S. \& Moon, D. (2009). "Audit and Non-Audit Fees and Capital Market Perceptions of Auditor Independence," Journal of Accounting Public Policy, No. 28, Pp. 369-385.

Gujarati, D. (2004). Basic Econometrics, the Mcgraw-Hill Companies, New York.

Gul, F. A. \& Tsui, J. S. L. (2001). "Free Cash Flow, Debt Monitoring, and Audit Pricing: Further Evidence on the Role of Director Equity Ownership," Auditing: A Journal of Practice \& Theory, No. 20, Pp. 72-84.

Griffin, P. A., Lont, D. H. \& Sun, Y. (2010). "Agency Problems and Audit Fees: Further Tests of the Free Cash Flow Hypothesis," Accounting and Finance, 50, Pp. 321-350.

Hay, D. C., Knechel, W. R. \& Wong, N. (2006). "Audit Fees: A Meta-Analysis of the Effects of Supply and Demand Attributes," Contemporary Accounting Research, 23, Pp. 141-191.

Hay, D., Knechel, W. R. \& Ling, H. (2008). "Evidence on the Impact of Internal Control and Corporate Governance on Audit Fees," International Journal of Auditing, 12, Pp. 924.

Hayes, R., Dassen Roger, Schilder, A. \& Wallage, P. (2005). Principles of Auditing. An Introduction to International Standards of Auditing, 2nd Edition, Ed. Pearson Education.

Higgs, J. L. \& Skantz, T. R. (2006). "Audit and Nonaudit Fees and the Market's Reaction to Earnings Announcements," Auditing: A Journal of Practice and Theory, 25 (1), Pp. 1-26.

International Federation of Accountants (IFAC) (2009). International Standards on Auditing.

International Federation of Accountants (IFAC) (2010). Code of Ethics for Professional Accountants.

Jaba, E. (2002).' Statistica,' 3rd Ed., Editura Economică, București. 
Jensen, M. C. (1986). “Agency Costs of Free Cash Flow, Corporate Finance and Takeovers," American Economic Review, 76, Pp. 323-329.

Jensen, M. C. \& Meckling, W. H. (1976). “A Theory of Firm: Managerial Behavior, Agency Costs and Ownership Structure," Journal of Financial Economics, 3, Pp. 305360.

Krishnan, J., Sami, H. \& Zhang, Y. (2005). "Does the Provision of Non-Audit Services Affect Investor Perceptions of Auditor Independence?," Auditing: A Journal of Practice and Theory, 24 (2), 111-135.

Lebart, L., Piron, M. \& Morineau, A. (2006). 'Statistique Exploratoire Multidimensionnelle. Visualisation Et Inférences En Fouille De Données,' 4e Édition, Dunod, Paris.

Lyon, J. D. \& Maher, M. W. (2005). "The Importance of Business Risk in Setting Audit Fees: Evidence from Cases of Client Misconduct," Journal of Accounting Research, 43, Pp. 133-151.

Mcmeeking, K. P. (2000). 'An Empirical Analysis of the Level and Changes of UK Audit and Non-Audit Services Fees,' Phd Dissertation (Lancaster University, 2000).

Moizer, P. (1997). “Auditor Reputation: The International Empirical Evidence," International Journal of Auditing, 1 (1), Pp. 61-74.

Nikkinen, J. \& Sahlström, P. (2004). "Does Agency Theory Provide a General Framework for Audit Pricing?," International Journal of Auditing, No. 8, Pp. 253-262.

Niemi, L. (2002). "Do Firms Pay for Audit Risk? Evidence on Risk Premiums in Audit Fees After Direct Control for Audit Effort," International Journal of Auditing, 6, Pp. 3751.

O'Keefe, T. P., Simunic, D. A. \& Stein, M. T. (1994). "The Production of Audit Services: Evidence from a Major Accounting Firm," Journal of Accounting Research, 32 (2), Pp. 241-261.
O'Sullivan, N. (2000). “The Impact of Board Composition and Ownership on Audit Quality: Evidence from Large UK Companies," British Accounting Review, 32, Pp. 397-414.

O'Sullivan, N. (2009). "The Impact of Directors' and Officers' Insurance on Audit Pricing: Evidence from UK Companies," Accounting Forum, No. 33, Pp. 146-161.

Palmrose, Z.- V. (1986). “Audit Fees and Auditor Size: Further Evidence," Journal of Accounting Research, 24, 97-110.

Pickett, K. H. S. (2006). Audit Planning: A Risk-Based Approach, John Wiley \& Sons Inc, New Jersey.

Pratt, J. \& Stice, J. D. (October 1994). "The Effect of Client Characteristics on Auditor Litigation Risk Judgments, Required Audit Evidence, and Recommended Audit Fees," The Accounting Review, No. 69, Pp.639-656.

Rainsbury, E. A., Bradbury, M. \& Cahan, S. F. (2009). "The Impact of Audit Committee Quality on Financial Reporting Quality and Audit Fees," Journal of Contemporary Accounting \& Economics, No. 5, Pp. 20-33.

Redmayne, N. B., Bradbury, M. E. \& Cahan, S. F. (2011). "The Association between Audit Committees and Audit Fees in the Public Sector," International Journal of Auditing, Pp. 1-15.

Securities and Exchange Commission (SEC), (2001). "Final Rule: Revision of the Commission's Auditor Independence Requirements," File No. S7-13-00. Government Printing Office, Washington, D.C.

Simunic, D. A. (Spring 1980). "The Pricing of Audit Services: Theory and Evidence," Journal of Accounting Research, Pp.161-190.

Soltani, B. (2003). 'Auditing: An International Approach,' Prentice Hall, Pearson Education, Essex. 
Smith, M. (2003). Research Methods in Accounting, SAGE Publication, London.

Walker, P. L. \& Casterella, J. R. (2000). "The Role of Auditee Profitability in Pricing New Audit Engagements," Auditing: A Journal of Practice and Theory, Vol. 19, Pp. 157-67.
Zaman, M., Hudaib, M. \& Haniffa, R. (2011). "Corporate Governance Quality, Audit Fees and Non-Audit Services Fees," Journal of Business Finance \& Accounting, 38 (1) \& (2), Pp. 165-197. 